Lucrările Seminarului Geografic Dimitrie Cantemir

Vol. 45, October 2017, pp. 179-190

http://dx.doi.org/10.15551/lsgdc.v45i0.15

\title{
Joint ecological, geographical and planning vision of the components of urban socio-ecological complexes
}

\author{
Alexandru-Ionuţ Petrişor ${ }^{1}$ \\ ${ }^{1}$ Ion Mincu University of Architecture and Urban Planning, Bucharest, Romania.
}

To cite this article: Petrișor, A.-I. (2017). Joint ecological, geographical and planning vision of the components of urban socio-ecological complexes. Lucrările Seminarului Geografic Dimitrie Cantemir, Vol. 45, pp. 179-190. DOI: 10.15551/lsgdc.v45i0.15

To link to this article: http://dx.doi.org/10.15551/lsgdc.v45i0.15 


\title{
JOINT ECOLOGICAL, GEOGRAPHICAL AND PLANNING VISION OF THE COMPONENTS OF URBAN SOCIO-ECOLOGICAL COMPLEXES
}

\author{
Alexandru-Ionuţ Petrişor ${ }^{1}$
}

\begin{abstract}
Since geographers, ecologists and planners study the same reality, their opinions must somehow converge despite the different languages used. Starting from this premise, the present article attempts to build up a model of the urban socio-ecological complexes, including the components identified by each of the three disciplines through its primary focus, and re-interpret sustainability through this joint perspective. The model is based on four quadrants resulting from the two dichotomies characteristic to each discipline: natural vs. anthropic in geography and biotic vs. abiotic in ecology. The new vision allows for seeing the city as a connected green infrastructure providing ecosystem services which meet the human needs. If the connections are broken, biodiversity is reduced and the level of ecosystem services decreased, resulting into the dissatisfaction of people; proper planning, accounting for the environment, can increase biodiversity and its interconnectedness, growing the level of ecosystem services and welfare of the inhabitants. The model is used to analyze sustainability, which results from the intersection of the vertical pillars (economic, social, cultural, and environmental) with the multiple horizontal dimensions and projects itself unto the territory.
\end{abstract}

Keywords: system, territory, urban environment, model, sustainability

\section{Introduction}

The same territorial reality is described in different terms by the discipline dealing with it. For instance, Mândruţ (2013:65) considers that geographers focus on the human society, while ecologists and biologists are more concerned with the living realm (fauna and flora). Planners have, similarly to the geographers, a primary interest in the human society (Petrişor, 2011:5).

As a consequence of it, after embracing the systemic theory in the 1970', the three different disciplines used different terms for the base unit, but also exhibit different understandings of its structure and functions.

The base unit in geography is the geosystem, defined as "complex geographical system resulted from the evolution of relationships between relief, water, air, soil, organisms and man,

\footnotetext{
${ }^{1} \mathrm{PhD}$ (Ecology), PhD (Geography), Habil. (Urban planning), Associate Professor and Director, Doctoral School of Urban Planning, "Ion Mincu" University of Architecture and Urban Planning, Str. Academiei nr. 18-20, sector 1, cod 010014, Bucharest, Romania \& Senior Researcher I and Scientific Director, National Institute for Research and Development in Constructions, Urban Planning and Sustainable Spatial Development URBAN-INCERC, Şoseaua Pantelimon, nr. 266, sector 2, cod 021652, Bucharest, Romania, alexandru_petrisor@yahoo.com.
} 
and characterized by openness, oneness, organization, functionality, hierarchy and selfregulation" (Institutul de Lingvistică Iorgu Iordan, 1998) or "territorial unit hierarchically individualized in time and geographic space by the relationship between the geographical elements composing it (inserted in its own functional structure) through a specific landscape physiognomy and a certain energy potential and biological productivity" (Mehedinţi, 1900:38).

In ecology, the base unit is the ecosystem, defined by Arthur Tansley in 1935 as "system... including not only the organism-complex, but also the whole complex of physical factors forming what we call the environment" (Tansley, 1935). However, the interest of ecologists shifted in time towards the complexes of ecosystems (Petrişor, 2012), or "socioecological complexes".

In spatial planning, the base concept is "socio-spatial system" - sub-class of ecological systems characterized by the presence of people and their activities (Botez, Celac, 1980). Nevertheless, the concept of "landscape" is also used and defined as unit formed by the interaction of man and nature over time and its perception by population (IUCN, 1994; Petrişor, 2013b).

Several previous studies attempted to find correspondences and link the different perspectives (Petrişor, Sârbu, 2010; Petrişor, 2011, 2012; Nemeş and Serac, 2012) and found out that the dialogue is possible, and the main concepts can be 'translated' by each discipline from the language of the others. However, the correspondences should be used only as a starting point to build up a joint approach (Petrişor, 2011). Therefore, this article aims to present a joint model of the urban socio-ecological complexes starting from the ecological, geographical and planning visions of their components. The choice of the urban environment was due to the fact that geographers and planners are mainly focused on the human society (Mândruţ, 2013:65), and the visions of the natural systems do not vary as much across the three disciplines.

\section{The joint model of urban socio-ecological complexes}

Ecologists are still debating whether cities are ecological systems or not, due to the strong anthropic influence, which alters their structure and functions (Petrişor, 2010, 2013a). The concept of 'urban ecosystem' is also debated, partially due to scale and complexity issues (Petrişor, 2013a). Two models, one produced by planners (Sârbu, 1999) and the other by ecologists (Petrişor, 2013a) were used as building blocks of the joint one (Figure 1).

Nevertheless, the main premise is that geographers and planners focus on the human society, and divide the reality into "natural vs. anthropic", and ecologists, concerned with the fauna and flora, divide the same reality into "abiotic vs. biotic". Therefore, the joint model (Figure 1) places the components of interest to each discipline in the four quadrants resulting from the two binary splits of reality.

Species are situated in the biotic area according to the ecologists; however, their classification depends on the relationship with humans; those species that cannot exist in the presence of human, called hemerophobous (Petrişor, 2013a) can be found only in the natural systems. At the antipode, hemerophile species, seeking for the human presence, and particularly the synanthropic ones, joining the man throughout the expansion of human settlements (Petrişor, 2013a), are characteristic to the anthropic realm. There are some species which manifest indifference to the humans, called hemerodiaphore, but also species classified from different perspectives as ubiquitous, opportunistic, invasive, or random, which can be found in both natural and anthropic systems. 


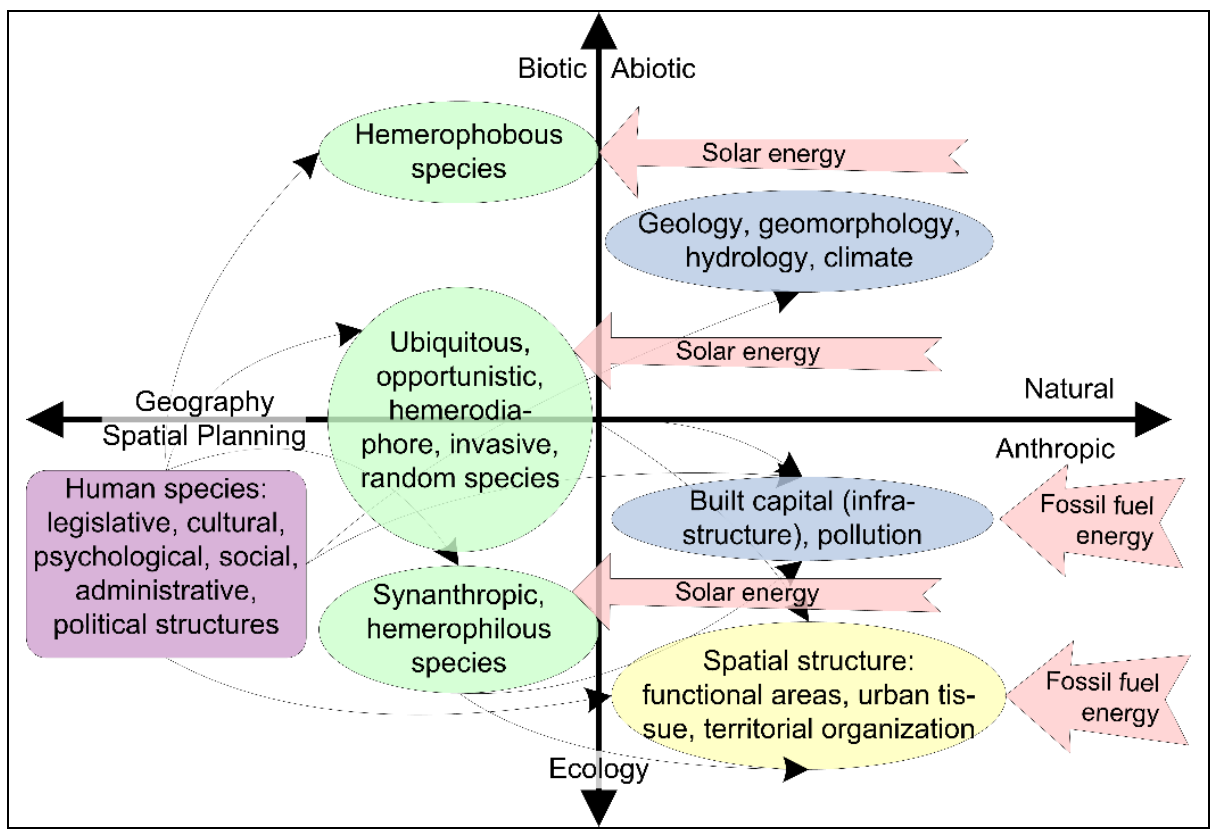

Figure 1: Schematics of a joint ecological, geographical and planning vision of the components of urban socio-ecological complexes

The human presence is manifested form a biotic perspective by the human species, but also through its characteristic structures, since the human being is a social species (Petrişor, 2008b) and through structures resulted from the noo-trophy (Petrişor, 2012); the first ones include psychological (e.g., the packing habit), social and cultural structures, and the second includes legislative, administrative and political structures. All of them set their fingerprint over the abiotic component, resulting into the built (infrastructural) capital and pollution due to the human activities, and spatially into the spatial structure: functional areas, urban tissue and territorial structure.

The natural abiotic component consists of the geology, geography, pedology, geomorphology, hydrology, atmosphere and climate characteristic to the place, but modified and the micro-scale by the effects of human activities (e.g., heat islands, wind canyons, soil sealing etc.).

Functionally, the urban systems have a reduced biodiversity (which alters their stability), and due to this fact they cannot generate the primary yield (Petrişor, 2013a). Therefore, despite the availability of solar energy, the anthropic structures rely on outer energy (Sârbu, 1999), obtained at large from the fossil fuels. In general, cities can be considered sinks or consumers of ecosystem services (Andrade et al., 2013).

\section{An economic perspective}

In an article published in 2013, Sarah Taylor Lovell and John R. Taylor described the urban landscape as a mosaic of natural corridors and small fragmented natural areas (Taylor Lovell and Taylor, 2013). This feature is explained by the fact that today, when urban development is the result of a controlled process named spatial planning, the urban shape is the output of negotiations between planners, local authorities and citizens (Lacaze, 1990). The existing idea that the natural capital provides to the human society goods and services, recently 
brought back to the public discourse through the concept of ecosystem services (Zakri and Watson, 2003; Watson and Zakri, 2005) provided by the green infrastructure (European Commission, 2013) provides solid arguments for pleading in favor of the urban biodiversity during the negotiation process (Clergeau, 2015). More exactly, in a socio-ecological complex, the green infrastructure represents the ecological foundation providing goods and services to the humans (the concept of ecosystem services embeds goods through the provision service). Biodiversity, preserved in the cities by the green infrastructure (Tzoulas et al., 2007), depends on the spatial structure of cities - more exactly, on the size and connectivity of natural areas (Melles et al., 2003) - and, in its turn influences the level of ecosystem services (Niemelä et al., 2010).

From a historical perspective, socio-economic systems extended in space under the demographic pressure seeking for new resources. Moreover, the anthropization and urbanization are a manifestation of the tendency to organize the adjacent territories in order to meet the basic needs (Petrişor and Sârbu, 2010; Petrişor, 2017). Since the share of urban population is increasing continuously (Grimm et al., 2008), the expansion of settlements and need for their interconnections through the road infrastructure resulted into the replacement of natural systems by artificial ones, and simplification and fragmentation of the remaining ones (Marzluff and Ewing, 2001; Petrişor and Sârbu, 2010; Petrişor, 2012), and ultimately in the 'global changes' (Dale, 1997; Dale et al., 2011): land cover and use changes, climate changes and alteration of energy flows. Although these changes were attributed to demography (Li et al., 2015) or economy (Jongman, 2002; Petrişor, 2015b; Petrişor et al., 2010, 2014, 2016b), fragmentation appears to be a more prominent cause of fragmentation than agriculture (Marzluff and Ewing, 2001), inducing land cover and use changes (Grimm et al., 2008; Crăciun, 2014; Gavrilidis et al., 2015; Vâlceanu et al., 2015), leading to environmental conflicts (Herspeger et al. 2015; Grădinaru et al., 2014; Tudor et al., 2014; Iojă et al., 2011, 2014) and decreasing the overall resilience (Andersson et al., 2014).

The fragmentation process, associated to the urban sprawl (Razin and Rosentraub, 2000; Fernández-Juricic and Jokimäki, 2001; Melles et al., 2003; Irwin and Bockstael, 2007) takes place in a similar way in natural and anthropic systems (Cumming, 2011). Thus, urban sprawl is the main threat to the natural areas (La Greca et al., 2011), but also to the cities. As a result, the low connectivity of natural parcels, low biodiversity, rapid succession and presence of invaders are the characteristic to urban ecological systems (Niemelä, 1999; McMahon, 2000; Benedict and McMahon, 2001; Gibb and Hochuli, 2002; Luck and Wu, 2002; McKinney, 2002; Schneider and Woodcock, 2008; Poelmans and Van Rompaey, 2009; Niemelä et al., 2010; Taylor Lovell and Taylor, 2013; Andersson et al., 2014; Petrişor, 2015a; Petrişor et al., 2016a).

Fragmentation reduces the nature of cities to four categories: remains of natural systems, their extensions, landscaped areas and spontaneous, invasive, or ruderal species (Qureshi and Breuste, 2010; Breuste et al., 2013). The low biodiversity impedes primary yield and reduces stability (Petrişor, 2015a; Petrişor, 2017). However, the few natural areas are crucial for maintaining the ecosystem services required by the human population (Acasandre and Crăciun, 2015; Enache and Popa, 2015), especially if they are connected by corridors (Clergeau, 1999, 2015, 2016; Niemelä, 1999). Responsible urban planning and management, paying respect to the environment (Ianoş et al., 2009, 2010), can provide lessons for reconciling with the nature (Fernández-Juricic and Jokimäki, 2001; Ersoy et al., 2015; Mierzejewska, 2015; Badiu et al., 2016). Last but not least, the interdisciplinary dialogue is a condition for achieving this goal (Wu, 2006; Ungureanu and Bănică, 2008; Bănică, 2010; Ianoş et al., 2013; Constantinescu and Platon, 2015; Frone and Constantinescu, 2015). 
This conceptual framework provides the grounds for a prudent planning, able to improve the relationship between the natural and anthropic systems (Fernández-Juricic and Jokimäki, 2001), increasing the level of ecosystem services and contributing to the growth of human welfare, resulting into sustainable communities (ODPM, 2006). Fig.-ure 2 presents the schematics of the theoretical concepts and their relationships; the circle can be equally vicious or virtuous, depending of the inclusion of environmental criteria into the planning process. If planners ignore the need of connectivity in order for the green infrastructure to provide ecosystem services, the result is a city with low biodiversity and citizens whose needs are not satisfied. If the biodiversity is increased 'honestly' (e.g., not using alien species or favoring the intrusion of invaders) and its connectivity ensured by green corridors, the result is a 'biodiversitary city' (Clergeau, 2015) with citizens able to benefit upon the ecosystem services.

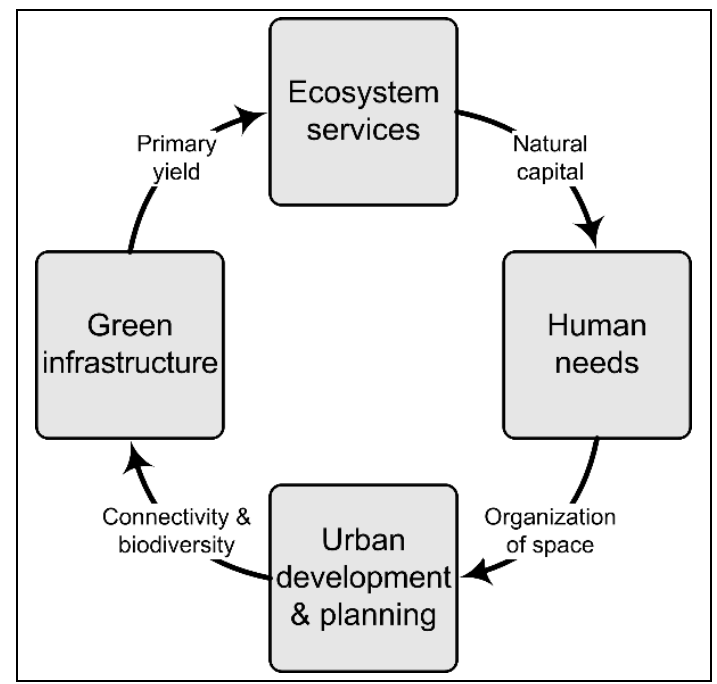

Figure 2: Schematics of the vicious and virtuous planning circles, depending on the level of biodiversity and its interconnectedness

\section{Sustainability as dynamic of coupled socio-ecological systems}

In order to harmonize the anthropocentric perspective of development, often focused on economy only, and ignoring societal and environmental consequences, usually adverse, dr. Gro Harlem Brundtland defined sustainability as "development that meets the needs of the present without compromising the ability of future generations to meet their own needs" (Brundtland, 1987); according to the author, the definition does not require a revision, but only fine tuning consisting of refocusing on the integration of pillars instead of overemphasizing each of them (Bugge and Waters, 2003). In relationship to the economic theory presented in the previous chapter, sustainability, presuming the ecological restoration of the systems affected by the anthropic impact, allows for a co-development of the human and natural capitals (Vădineanu, 2001).

Although most authors recognize only the traditional pillar - economy, society and environment (Basiago, 1999; Littig and Grießler, 2005; Gibson, 2006; Murphy, 2012; Petrişor and Petrişor, 2014), some authors add a fourth cultural pillar, recognizing its potential for economic growth (Hawkes, 2001), as a result of the lobby of United Cities and Local Governments (Petrişor and Petrişor, 2014; Todoran and Patachi, 2015). In addition to the pillars, sustainability has dimensions corresponding to the administrative/economic categories (Bottero 
and Feretti, 2010; Péti, 2012; Petrişor and Petrişor, 2014): management, design/ planning, transport, housing, agriculture, infrastructure, science, education, governance, ethics, health, technology, energy etc., and a territorial component (Mierzejewska, 2017), called spatial sustainability, and defined as "development providing for a territorial balance of satisfying at the same rate the economic, social and environmental needs of present and future generations" (Petrişor, 2008a), and ensures the coherence of socio-economic objectives in relationship with the territory and its ecological and cultural functions, aiming to enhance the quality of present and future generations' life by creating sustainable communities able to manage and use resources efficiently, exploiting the innovative ecological and social potential of the economy and guaranteeing the welfare, environmental protection and social cohesion (Collignon, 1998). The resulting concepts are polycentricity, cohesion and sustainable communities (Petrişor, 2017), although it is arguable whether spatial sustainability is a concept similar to the spatial dimension of sustainability (Petre, 2016; Mierzejewska, 2017).

In summary, sustainability emerges at the intersection between the vertical pillars and horizontal dimensions, acting like a prism which projects development unto the territory through the multiple facets resulting from the synergic interactions between its pillars and dimensions (Figure 3).

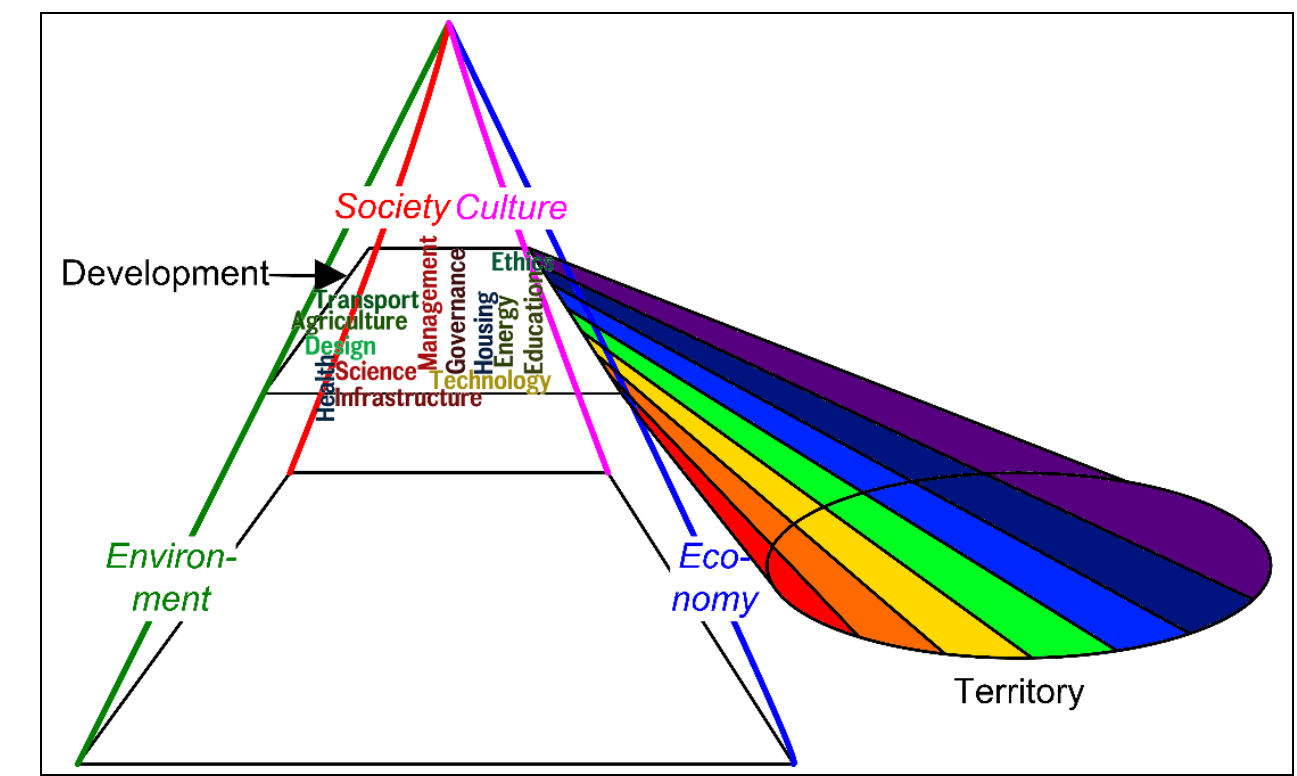

Figure 3: Sustainability results from the intersection of the vertical pillars with the horizontal dimensions and projects unto the territory

\section{Conclusions}

This article attempted to build on the premise that, since geographers, ecologists and planners study the same reality, their opinions must somehow converge despite the different languages used, a model of the urban socio-ecological complexes. The exercise was successful and showed that the different perspectives can be harmonized if the components identified by each discipline are placed within the epistemic quadrants defined by the "natural vs. anthropic" and "abiotic vs. biotic" understandings of reality.

The new concepts allow for seeing the city as a connected green infrastructure providing ecosystem services which meet the human needs. If the connections are broken, 
biodiversity is reduced and the level of ecosystem services decreased, resulting into the dissatisfaction of people; proper planning, accounting for the environment, can increase biodiversity and its interconnectedness, growing the level of ecosystem services and welfare of the inhabitants.

From a dynamic perspective, sustainability ensures the co-development of the natural and anthropic components of the environment, placed conceptually at the intersection of the vertical pillars (economy, society, environment and culture) with the horizontal dimensions, and reflected from a spatial perspective in the territory.

\section{Acknowledgements}

The author is grateful to Dr. Alexandru Bănică from the Faculty of Geography and Geology at Alexandru Ioan Cuza University of Iaşi for the fruitful and constructive discussions during the 26th edition of "Dimitrie Cantemir" International Geographic Seminar in 2016, which drafted the idea of the present article, and to Mrs. Raluca Petre, Director of URBANPROIECT Branch at NIRD URBAN+INCERC, for the debates on sustainability which allowed for refining the theory presented in the last chapter.

The last chapter is an output of phase "Defining and operating the concept of territorial sustainability" of the Nucleus project "Durable or sustainable development? Defining the concepts and drafting the construction of the sustainability index", carried out within the Nucleus program "Integrated research for the resilience, efficiency, safety and comfort of the built environment" by the National Institute for Research and Development in Constructions, Urbanism and Sustainable Spatial Development URBAN-INCERC and funded by the National Authority for Scientific Research and Innovation.

\section{References}

1. Acasandre A., Crăciun C., 2015. Social Movements against the Destruction of Green Public Spaces - Case Study: the "Alexandru Ioan Cuza" (IOR) Park, Bucharest, in: Sandu A., Frunză A., Ciulei T., Gorghiu G., Petrovici A. (Eds.), LUMEN: Rethinking Social Action. Core Values, Medimond Monduzzi International Proceedings Division, Bologna, Italy, pp. 7-16.

2. Andersson E., Barthel S., Borgström S., Colding, J., Elmqvist T., Folke C., Gren Å., 2014. Reconnecting Cities to the Biosphere: Stewardship of Green Infrastructure and Urban Ecosystem Services. Ambio, 43(4), 445-453, Springer, New York, NY, USA.

3. Andrade G. I., Remolina F., Wiesner D., 2013, Assembling the pieces: a framework for the integration of multi-functional ecological main structure in the emerging urban region of Bogotá, Colombia. Urban Ecosystems, 16, 723, Springer, New York, NY, USA.

4. Badiu D. L., Iojă I. C., Pătroescu M., Breuste J., Artmann M., Niţă M. R., Grădinaru S. R., Hossu C. A., Onose D. A., 2016. Is urban green space per capita a valuable target to achieve cities'sustainability goals? Romania as a case study. Ecological Indicators, 70, 53-66, Elsevier, Amsterdam, The Netherlands.

5. Basiago A. D., 1999. Economic, social, and environmental sustainability in development theory and urban planning practice. The Environmentalist, 19, 145-161, Elsevier, Amsterdam, The Netherlands.

6. Bănică A., 2010. Sustainable urban development indicators. Case study: Târgu Ocna town. Present Environment and Sustainable Development, 4, 339-352, "Alexandru Ioan Cuza" University Publishing House, Iaşi, Romania.

7. Benedict M. A., McMahon E. T., 2001. Green Infrastructure: Smart Conservation for the 21st Century. Sprawl Watch Clearinghouse Monograph Series, Washington, DC, USA. 
8. Botez M. C., Celac M., 1980. Sistemele spaţiului amenajat: modelare - optimizare - previziune, Editura Ştiinţifică şi Enciclopedică, Bucharest, Romania, pp. 37-41.

9. Bottero M., Ferretti V., 2010. Integrating the analytic network process (ANP) and the driving forcepressure-state-impact-responses (DPSIR) model for the sustainability assessment of territorial transformations. Management of Environmental Quality: An International Journal, 21(5), 618644, Emerald Group Publishing, Bingley, UK.

10. Breuste J., Qureshi S., Li J., 2013. Scaling down the ecosystem services at local level for urban parks of three megacities. Hercynia N. F., 46, 1-20, Martin-Luther-University Halle-Wittenberg, Halle, Germany.

11. Brundtland G. H., 1987. Our Common Future. WCED, Oxford University Press, Oxford, UK.

12. Bugge H. C., Watters L., 2003. A Perspective on Sustainable Development after Johannesburg on the Fifteenth Anniversary of Our Common Future: An Interview with Gro Harlem Brundtland. Georgetown International Environmental Law Review, 15, 359-366, Georgetown University Law Center, Washington, DC, USA.

13. Clergeau P., 2015. Manifeste pour la ville biodiversitaire, Éditions Apogée, Rennes, France, 69 pp.

14. Clergeau P., Désiré G., 1999. Biodiversité, paysage et aménagement du corridor à la zone de connexion biologique. Mappemonde, 55, 3, 19-23, University of Avignon, Avignon, France.

15. Clergeau P., Linglart M., Dangeon M., Morin S., Paris M., 2016. La trame verte et bleue à l'épreuve de la ville, Traits urbains, 83, 37-40, Forum des Projets Urbains, Paris, France.

16. Constantinescu A., Platon V., 2015. Sustainable development paradigm - synopsis. Annals of the University of Oradea, Economic Science Series, 23(1), 116-124, University of Oradea, Oradea, Romania.

17. Collignon P., 2009. Situation et défis du monde rural - Le patrimoine et le paysage au cœur des enjeux du développement territorial durable. Aménagement du territoire européen et paysage, 88 , 99-103, Conseil de l'Europe, Brussels, Belgium.

18. Crăciun C., 2014. The Vulnerability of Fragile Landscape and Complex Hazards Areas with Potential Risks and Specific Types of Hazards and Vulnerabilities of the Natural, Anthropic and Cultural Landscape in Brăila County, Romania, in: Boştenaru Dan M., Armaş I., Goretti A. (Ed.), Earthquake Hazard Impact and Urban Planning, Springer, Earth Sciences \& Geography - Natural Hazards Series, Amsterdam, The Netherlands, vol. 13, pp. 67-81.

19. Cumming G. S., 2011. Spatial resilience: integrating landscape ecology, resilience, and sustainability. Landscape Ecology, 26(7), 899-909, Springer, New York, NY, USA.

20. Dale V. H., 1997. The relationship between land-use change and climate change. Ecological Applications, 7(3), 753-769, John Wiley \& Sons Inc., Malden, MA, USA.

21. Dale V. H., Efroymnson R. A., Kline K. L., 2011. The land use - climate change - energy nexus. Landscape Ecology, 26(6), 755-773, Springer, New York, NY, USA.

22. Enache C., Popa A., 2015. Urban Agriculture. Perception-Awareness-Necessity, in: Sandu A..Frunză A., Ciulei T., Gorghiu G., Petrovici A. (Eds.), LUMEN: Rethinking Social Action. Core Values, Medimond Monduzzi International Proceedings Division, Bologna, Italy, pp. 531-535.

23. Ersoy E., Jorgensen A., Warren P. H., 2015. Measuring the Spatial Structure of Urban Land Uses. The Case of Sheffield, UK. Journal of Environmental Protection and Ecology, 16(1), 393-401, Balkan Environmental Association, Thessaloniki, Greece.European Commission, 2013. Building a Green Infrastructure for Europe, Luxembourg: Publications Office of the European Union, Brussels, Belgium, 24 pp.

24. Fernández-Juricic E., Jokimäki J., 2001. A habitat island approach to conserving birds in urban landscapes: case studies from southern and northern Europe. Biodiversity and Conservation, 10, 2023-2043, Springer, New York, NY, USA.

25. Frone S., Constantinescu A., 2015. Ecosystem approach outcomes of a regional metabolism. Quality - Access to Success, 16, 56-64, Romanian Society for Quality Assurance, Bucharest, Romania.

26. Gavrilidis A. A., Grădinaru S. R., Iojă I. C., Cârstea E. M., Pătru-Stupariu I., 2015. Land use and land cover dynamics in the periurban area of an industrialized East-European city. An overview of the last 100 years. Carpathian Journal of Earth and Environmental Sciences, 10(4), 29-38, North University of Baia Mare, Baia Mare, Romania. 
27. Gibb H., Hochuli D. F., 2002. Habitat fragmentation in an urban environment: large and small fragments support different arthropod assemblages. Biological Conservation, 106(1), 91-100, Elsevier, Amsterdam, The Netherlands.

28. Gibson R. B., 2006. Beyond the pillars: sustainability assessment as a framework for effective integration of social, economic and ecological considerations in significant decision-making. Journal of Environmental Assessment Policy and Management, 8(3), 259-280, World Scientific, Shanghai, China.

29. Grădinaru S. R., Iojă I. C., Onose D. A., Gavrilidis A. A., Pătru-Stupariu I., Kienast F., Hersperger A. M., 2014. Land abandonment as a precursor of built-up development at thesprawling periphery of former socialist cities. Ecological Indicators, 57, 305-313, Elsevier, Amsterdam, The Netherlands.

30. Grimm N. B., Faeth S. H., Golubiewski N. E., Redman C. L., Wu J., Bai X., Briggs J. M., 2008. Global Change and the Ecology of Cities. Science, 319(5864), 756-760, American Association for the Advancement of Science, Washington, DC, USA.

31. Hawkes J., 2001. The fourth pillar of sustainability: Culture's essential role in public planning. Melbourne, Australia.

32. Hersperger A. M., Iojă I. C., Steiner F., Tudor C. A., 2015. Comprehensive consideration of conflicts in the land-use planning process: a conceptual contribution. Carpathian Journal of Earth and Environmental Sciences, 10(4), 5-13, North University of Baia Mare, Baia Mare, Romania.

33. Ianoş I., Humeau J.-B., Tălângă C., Braghină C., Ancuţa C., Bogdan L., 2010. Ethics of space and the treatment of most disadvantaged areas. Carpathian Journal of Earth and Environmental Sciences, 5(2), 203-210, North University of Baia Mare, Baia Mare, Romania.

34. Ianoş I., Peptenatu D., Zamfir D., 2009. Respect for environment and sustainable development. Carpathian Journal of Earth and Environmental Sciences, 4(1), 81-93, North University of Baia Mare, Baia Mare, Romania.

35. Ianoş I., Petrişor A.-I., Zamfir D., Cercleux A. L., Stoica I. V., 2013. In search of a relevant indicator measuring territorial disparities in a transition country. Case study: Romania. Die Erde 144(1), 69-81, Geographical Society of Berlin, Berlin, Germany.

36. Institutul de Lingvistică Iorgu Iordan, 1998. Dicţionar explicativ al limbii române, Editura Univers Enciclopedic, Bucharest, Romania, $1194 \mathrm{pp.}$

37. Iojă I. C., Niţă M. R., Vânău G. O., Onose D. A., Gavrilidis A. A., 2014. Using multi-criteria analysis in identifying spatial land-use conflicts in the Bucharest Metropolitan Area. Ecological Indicators, 42(1), 112-121, Elsevier, Amsterdam, The Netherlands.

38. Irwin E. G., Bockstael N. E., 2007. The evolution of urban sprawl: Evidence of spatial heterogeneity and increasing land fragmentation. Proceedings of the National Academy of Sciences, 104(52), 20672-20677, National Aacdemy of Sciences of the United States of America, Washington, DC, USA.

39. IUCN, 1994. Guidelines for protected areas management categories, Cambridge, UK, $261 \mathrm{pp}$.

40. Jongman R. H. G., 2002. Homogenisation and fragmentation of the European landscape: ecological consequences and solutions. Landscape and Urban Planning, 58(2-4), 211-221, Elsevier, Amsterdam, The Netherlands.

41. La Greca P., La Rosa D., Martinico F., Privitera R., 2011. Agricultural and green infrastructures: The role of non-urbanised areas for eco-sustainable planning in a metropolitan region. Environmental Pollution, 159(8-9), 2193-2202, Elsevier, Amsterdam, The Netherlands.

42. Lacaze J.-P., 1990. Les méthodes de l'urbanisme. 2e édition corrigée, Presses Universitaires de France, Paris, France, 127 pp.

43. Li F., Zhang S., Bu K., Yang J., Wang Q., Chang L., 2015. The relationships between land use change and demographic dynamics in western Jilin province. Journal of Geographical Sciences, 25(5), 617-636, Springer, New York, NY, USA.

44. Littig B., Grießler E., 2005. Social sustainability: a catchword between political pragmatism and social theory. International Journal of Sustainable Development, 8(1-2), 65-79, Inderscience, Olney, Bucks, UK. 
45. Luck M., Wu J., 2002. A gradient analysis of urban landscape pattern: a case study from the Phoenix metropolitan region, Arizona, USA. Landscape Ecology, 17, 327-339, Springer, New York, NY, USA.

46. Mândruţ O., 2013. Elemente de epistemologie a geografiei, „Vasile Goldiş” University Press, Arad, Romania, $150 \mathrm{pp}$.

47. Marzluff J. M., Ewing K., 2001. Restoration of Fragmented Landscapes for the Conservation of Birds: A General Framework and Specific Recommendations for Urbanizing Landscapes. Restoration Ecology, 9(3), 280-292, John Wiley \& Sons Inc., Malden, MA, USA.

48. McKinney M. L., 2002. Urbanization, Biodiversity, and Conservation. BioScience, 52(10), 883-890, Oxford University Press, Oxford, UK.

49. McMahon E. T., 2000. Green Infrastructure. Planning Commissioner Journal, 37, 4-7, Planning Commission, Burlington, VT, USA.

50. Mehedinţi S., 1900. Eterogenitatea celor patru sfere, Bucharest, Romania.

51. Melles S., Glenn S., Martin K., 2003. Urban bird diversity and landscape complexity: Species environment associations along a multiscale habitat gradient. Conservation Ecology, 7(1), 5, Resilience Alliance, Wolfville, Nova Scotia, Canada.

52. Mierzejewska L., 2015. Sustainable Development in Physical Planning and Spatial Development in Poland. Biuletyn Komitet Przestrzennego Zagospodarowania Kraju, 257-258, 96-117, Committee for Spatial Economy and Regional Planning, Polish Academy of Sciences, Warsaw, Poland.

53. Mierzejewska L., 2017. Rozwój zrównoważony miasta: Podejście systemowe (Sustainable Development of a City: Systemic Approach). Problemy ekorozwoju - Problems of sustainable development, 12(1), 71-78, European Academy of Science and Arts, Salzburg, Austria.

54. Murphy K., 2012. The social pillar of sustainable development: a literature review and framework for policy analysis. Sustainability: Science, Practice, \& Policy, 8(1), 15-29, Society of Environmental Journalists, Jenkintown, PA, USA.

55. Nemeş V., Serac C., 2012. The city seen as an ecosystem. Theoretical approach. Analele Universităţii din Oradea, Fascicula Protecţia Mediului, 19, 745-750, Editura Universităţii din Oradea, Oradea, Romania.

56. Niemelä J., 1999. Ecology and urban planning. Biodiversity and Conservation, 8(1), 119-131, Springer, New York, NY, USA.

57. Niemelä J., Saarela S.-R., Söderman T., Kopperoinen L., Yli-Pelkonen V., Väre S., Kotze D. J., 2010. Using the ecosystem services approach for better planning and conservation of urban green spaces: a Finland case study. Biodiversity and Conservation, 19, 3225-3243, Springer, New York, NY, USA.

58. Office of the Deputy Prime Minister - ODPM, 2006. A common approach to creating sustainable communities: "The Bristol Accord", in: UK Presidency. EU Ministerial Informal on Sustainable Communities. Policy Papers, ODPM Publications, London, UK, Document 05 EUPMI 03656/A, $41 \mathrm{pp}$.

59. Péti M., 2012. A territorial understanding of sustainability in public development. Environmental Impact Assessment Review, 32(1), 61-73, Elsevier, Amsterdam, The Netherlands.

60. Petre R., 2016. Dezvoltare durabilă versus dezvoltare teritorială durabilă / Sustainable development versus sustainable territorial development. Revista Școlii Doctorale de Urbanism, 1, 5-14, Universitatea de Arhitectură şi Urbanism „Ion Mincu”, Bucharest, Romania.

61. Petrişor A.-I., 2008a. Către o definiţie a dezvoltării spaţiale durabile. Amenajarea Teritoriului şi Urbanismul, 7(3-4),1-5, Editura Alfa, Iaşi, Romania.

62. Petrişor A.-I., 2008b. Ecologie urbană, dezvoltare spaţială durabilă şi legislaţie, Editura Fundaţiei România de mâine, Bucharest, Romania.

63. Petrişor A.-I., 2010. Mediul urban: o abordare ecologică. Revista Urbanistique, http://www.urbanistique.ro/mediul-urban-o-abordare-ecologica-dr-alexandru-ionutpetrisor/\#more-127

64. Petrişor A.-I., 2011. Systemic theory applied to ecology, geography and spatial planning. Theoretical and methodological developments, Lambert Academic Publishing GmbH \& Co. KG, Saarbrücken, Germany, 172 pp. 
65. Petrişor A.-I., 2012. Comparative critical analysis of systems studied by ecology, geography and spatial planning. Geopolitics, History, and International Relations, 4(2), 289-303, Addleton Academic Publishers, New York, NY, USA.

66. Petrişor A.-I., 2013a. Are human settlements ecological systems? Oltenia. Studii şi comunicări. Ştiinţele Naturii, 29(1), 227-232, Muzeul de Ştiinţe Naturale al Olteniei, Craiova, Romania.

67. Petrişor A.-I., 2013b. Landscapes in a planning framework: time and scale issues, Landscapes: perception, knowledge, awareness and action. Abstract Proceedings, Editura Fundaţiei România de mâine, Bucharest, Romania, pp. 97

68. Petrişor A.-I., 2015a. Assessment of the Green Infrastructure of Bucharest using CORINE and Urban Atlas data. Urbanism Architecture Constructions, 6(2), 19-24, INCD URBAN-INCERC, Bucharest, Romania.

69. Petrişor A.-I., 2015b. Using CORINE data to look at deforestation in Romania: Distribution \& possible consequences, Urbanism Architecture Constructions, 6(1), 83-90, INCD URBANINCERC, Bucharest, Romania.

70. Petrişor A.-I., 2017. A diversity-based approach to the spatial development of socio-ecological systems. Urbanism Architecture Constructions, 8(2), 143-162, INCD URBAN-INCERC, Bucharest, Romania.

71. Petrişor A.-I., Andronache I. C., Petrişor L. E., Ciobotaru A. M., Peptenatu D., 2016a. Assessing the fragmentation of the green infrastructure in Romanian cities using fractal models and numerical taxonomy. Procedia Environmental Sciences, 32, 110-123, Elsevier, Amsterdam, The Netherlands.

72. Petrişor A.-I., Grigorovschi M., Meiţă V., Simion-Melinte C.-P., 2014. Long-term environmental changes analysis using CORINE data. Environmental Engineering and Management Journal, 13(4), 847-860, EcoZone, Iaşi, Romania.

73. Petrişor A.-I., Ianoş I., Tălângă C., 2010. Land cover and use changes focused on the urbanization processes in Romania. Environmental Engineering and Management Journal, 9(6), 765-771, EcoZone, Iaşi, Romania.

74. Petrişor A.-I., Meiţă V., Petre R., 2016b. Difficulties in achieving social sustainability in a biosphere reserve. International Journal of Conservation Science, 7(1), 123-136, "Alexandru Ioan Cuza" University Publishing House, Iaşi, Romania.

75. Petrişor A.-I., Petrişor L. E., 2014. 25 years of sustainability. A critical analysis. Present Environment and Sustainable Development, 8(1), 175-190, “Alexandru Ioan Cuza” University Publishing House, Iaşi, Romania.

76. Petrişor A.-I., Sârbu C. N., 2010. Dynamics of geodiversity and eco-diversity in territorial systems. Journal of Urban and Regional Analysis, 2(1), 61-70, Interdisciplinary Center of Advanced Research on Territorial Dynamics, Bucharest, Romania.

77. Poelmans L., Van Rompaey A., 2009. Detecting and modelling spatial patterns of urban sprawl in highly fragmented areas: A case study in the Flanders-Brussels region. Landscape and Urban Planning, 93(1), 10-19, Elsevier, Amsterdam, The Netherlands.

78. Qureshi S., Breuste J. H., 2010. Prospects of Biodiversity in the Mega-City of Karachi, Pakistan: Potentials, Constraints and Implications, in: Müller N., Werner P., Kelcey J. G. (Eds.), Urban Biodiversity and Design, 1st edition, Blackwell, Chichister, UK, pp. 497-517.

79. Razin E., Rosentraub M., 2000. Are Fragmentation and Sprawl Interlinked? North American Evidence. Urban Affairs Review, 35(6), 821-835, Sage, Thousand Oaks, CA, USA.

80. Sârbu C. N., 1999. Reabilitare urbană şi dezvoltare - o dimensiune principală a tranziţiei socioeconomice. Un exemplu de abordare: textura urbană, in: Vădineanu A. (Ed.). Dezvoltarea durabilă, Vol. al II-lea. Mecanisme şi instrumente, Editura Universităţii din Bucureşti, Bucharest, Romania, pp. 298-329.

81. Schneider A., Woodcock C. E., 2008. Compact, Dispersed, Fragmented, Extensive? A Comparison of Urban Growth in Twenty-five Global Cities using Remotely Sensed Data, Pattern Metrics and Census Information. Urban Studies, 45(3), 659-692, Sage, Thousand Oaks, CA, USA.

82. Tansley A. G., 1935. The use and abuse of vegetational concepts and terms, Ecology, 16, 284-307, Ecological Society of America, Washington, DC, USA. 
83. Taylor Lovell S., Taylor J. R., 2013. Supplying urban ecosystem services through multifunctional green infrastructure in the United States. Landscape Ecology, 28, 1447-1463, Springer, New York, NY, USA.

84. Todoran S. M., Patachi L., 2015. Cultural Sustainability and Issues of Urban Memory. Acta Technica Napocensis: Civil Engineering \& Architecture, 58(4), 227-234, Technical University of ClujNapoca, Cluj-Napoca, Romania.

85. Tudor C. A., Iojă I. C., Pătru-Stupariu I., Niţă M. R., Hersperger A., 2014. How successful is the resolution of land-use conflicts? A comparison of cases from Switzerland and Romania. Applied Geography, 47, 125-136, Elsevier, Amsterdam, The Netherlands.

86. Tzoulas K., Korpela K., Venn S., Yli-Pelkonen V., Kazmierczak A., Niemelä J., James P., 2007. Promoting Ecosystem and Human Health in Urban Areas using Green Infrastructure: A Literature Review. Landscape and Urban Planning, 81, 167-178, Elsevier, Amsterdam, The Netherlands.

87. Ungureanu I., Bănică A., 2008. Possibilities of operationalizing the concept of sustainable development in the spatial and functional evolution of Târgu Ocna town. Present Environment and Sustainable Development, 2(2), 165-187, “Alexandru Ioan Cuza” University Publishing House, Iaşi, Romania.

88. Vădineanu A., 2001. Decision making and decision support systems for balancing Socio-Economic and Natural Capital Development. Observatorio Medioambiental, 4, 19-47, Universidad Complutense de Madrid, Madrid, Spain.

89. Vâlceanu D. G., Suditu B., Petrişor A.-I., 2015. Romanian technological risk objectives (SEVESO). Effects on land use and territorial planning. Carpathian Journal of Earth and Environmental Sciences, 10(4), 201-208, North University of Baia Mare, Baia Mare, Romania.

90. Watson R., Zakri A. H., 2005. Ecosystems and Human Well-being. Synthesis, Island Press, Washington, DC, USA, $137 \mathrm{pp.}$

91. Wu J., 2006. Landscape ecology, cross-disciplinarity, and sustainability science. Landscape Ecology, 21(1), 1-4, Springer, New York, NY, USA.

92.Zakri A. H., Watson R., 2003. Ecosystems and Human Well-being. A Framework for Assessment, Island Press, Washington, DC, USA, 212 pp. 